ÁDÁM Воóc*

\title{
Observations on the Definition of Public Policy (Ordre Public) in Swiss Arbitration Law
}

\author{
Motto: ,Ein Schiedsgericht thront nicht \\ über der Erde, schwebt nicht in der Luft, \\ es muss irgendwo landen, \\ irgendwo erden." (Raape)
}

\begin{abstract}
This study deals with the notion of public policy (ordre public) in Swiss international arbitration. The paper analyzes the relevant paragraphs of IPRG, the Swiss Act on Private International Law. Based on legal authorities one can read about the distinction between procedural and substantive public policy in Swiss law. The paper describes several cases, in which the awards of the Court of Arbitration for Sport (Tribunal Arbitral du Sport) were challenged at the Federal Tribunal of Switzerland based on the alleged breach of public policy. The author discusses the question whether there can be a supra-national, universal interpretation of the notion of public policy in Swiss law, which is based on the fundamental legal and moral values of the civilized nations.
\end{abstract}

Keywords: international commercial arbitration, challenge of award, public policy, Switzerland

It is a well-known fact that one of the main advantages of arbitral dispute resolution is speed, expedition, the single instance nature of the procedure and the exclusion of an appeal, as a result only the challenge of the arbitral award may be initiated, exclusively under special conditions. ${ }^{1}$ In many cases the arbitral award may bring significant drawbacks for the unsuccessful party, which makes it likely that one may want to seize every opportunity in order to initiate the challenge of the arbitral award. ${ }^{2}$

One of the possible ways to challenge an arbitral award is on the grounds of public policy. ${ }^{3}$ In the present study we wish to examine how the Swiss arbitration law defines, interprets the definition of public policy, and what positions have been developed by the

* Research fellow, Institute for Legal Studies, Centre for Social Sciences, Hungarian Academy of Sciences, H-1014 Budapest, Országház u. 30; Lecturer, Department of Civil and Roman Law, Faculty of Law and Political Sciences, Károli Gáspár University, H-1042 Budapest, Viola u. 2-4. E-mail: adambooc@gmail.com

${ }^{1}$ For this see Gellért, Gy.: Új törvény a választottbíráskodásról (New Law on Arbitration). Magyar Jog, 45 (1995), 451-452; Boóc, Á.-Hegyi, A.-Sándor, I.-Szücs, B.-Török, G.: A követelések érvényesitésének jogi eszközei (The legal means of enforcing claims). Budapest, 2005. 260; Boóc, Á.: A kereskedelmi választottbíráskodás egyes kérdései (Certain dilemmas of commercial arbitration). In Balogh, M.: Diszciplinák határain innen és túl. Fiatal Kutatók Fóruma 2. (Beyond and above the borders of Disciplines. Forum of Young Researchers 2). Budapest, 2007. 111-112.

${ }^{2}$ In relation to the invalidation of an arbitration verdict, Hungarian language summary, see Horváth, É.-Kálmán, Gy.: A nemzetközi eljárások joga, különös tekintettel a választottbíráskodásra (The procedures of international law, particularly with regard to arbitration). Budapest, 2003. 121-126.

${ }^{3}$ For this summary see Kiss, K.: A Választottbiróság itéletének érvénytelenitése közrendbe ütközésre való hivatkozással. A hazai és a nemzetközi gyakorlat összehasonlitása (The invalidation of the arbitral tribunal judgments with reference to public policy conflict. A comparison of domestic and international law). Gazdaság és Jog, 13 (2005), 10-14. 
judicature in connection with this notion. As is well known, Switzerland is a popular venue for international arbitration procedures, which can be explained by numerous historical and legal historical reasons. ${ }^{4}$ In light of this the explanation of the definition of public policy is likely to result as useful experience for both domestic and international arbitration.

Our investigation in the present study shall be limiting its review to how the Swiss law on international commercial arbitration proceedings makes it possible for the arbitral award to be revoked on the legal basis of collision with public policy. ${ }^{5}$ Apart from this-brieflyrefer to the international private law interpretation of public policy in Swiss law. ${ }^{6}$

\section{I.}

It signifies the intense relationship between the Swiss international arbitration and the Swiss international private law that the basic rules applying to them are found in the same statute accepted on 18 December 1987 Federal Statute on Swiss international private law (Bundesgesetz über das internationale Privatrecht vom 18. Dezember 1987, hereinafter referred to as: IPRG). International commercial arbitration rules can be found in the 20th chapter of the IPRG. With reference to the work of French Yves Derains on the correlation of applicable law during public policy and arbitration process, it is important to highlight that throughout international commerce certain collision problems may arise during the arbitration procedure, therefore the rules of international private law may play an important role in arbitration procedures. ${ }^{7}$

It is essential to stress that the current form of the IPRG is a result of an approximately ten-year long process, after review of many drafts and amendments. ${ }^{8}$

The IPRG-neither in the private international law or international commercial arbitration part-does not define the concept of public policy, leaving it to a large extent to jurisprudence or case law to determine. In Arts 17, 18 and 19 of the IPRG we shall see the concept of public policy accepted in international private law, whereas in Art. 190 Para. 2 e) it is used as a phrase for grounds of revoking the arbitral award.

${ }^{4}$ Swiss arbitration law in Hungarian language summary, see Boóc, Á.: Nemzetközi kereskedelmi választottbiráskodás. A választottbiró megválasztása és kizárása (The international commercial arbitration. The voting and exclusion of a judge). Budapest, 2009. 51-60. For the development of Swiss private law see Hamza, G.: Entstehung und Entwicklung der modernen Privatrechtsordnungen und die römischrechtliche Tradition. Budapest, 2009. 236-256.

5 With regard to the Swiss national arbitration-which is primarily ruled by the accepted intercantonal convention on 27th of August 1969, named Interkantonale Konkordat vom 27. März 1969 über die Schiedsgerichtsbarkeit-we do not address. In relation to the Intercantonal Convention in detail see Bratschi, P.-Briner, R.: Bemerkungen zum Konkordat über die Schiedsgerichtsbarkeit. Schweizerische Juristen-Zeitung, 72 (1976), 101.

6 The public policy in private international law and arbitration proceedings established the concept of the new Hungarian literature summary see: Burián, L.: Gondolatok a közrend szerepéről (Thoughts on the function of public order). In: Kiss, D.-Varga, I. (eds): Magister artis boni et aequi. Studia in Honorem Németh János. Budapest, 2003. 99-122.

7 See Derains, Y.: Public Policy and the Law Applicable to the Dispute in International Arbitration. In: Comparative Arbitration Practice and Public Policy in Arbitration. ICCA Congress Series, No. 3. New York, 1986. 227-256.

${ }^{8}$ For this in detail see Blessing, M.: Introduction to Arbitration-Swiss and International Perspectives. Basel, 1999. 170-180. 
Article 17 of the IPRG states that the application of foreign law is excluded if it would lead to the outcome of incompatibility with Swiss public policy (ordre public). ${ }^{9}$ According to the provisions of Art. 18, the provisions of Swiss law must be applied in case specific goals make it necessary, regardless of the fact that the rules of the IPRG would impose the application of other laws, therefore here the present Article is capable of overwriting the law-prescribing function of collision laws. Art. 19 provides that provisions of another act may be considered if according to the Swiss legal mentality a party deserves to be protected and his clear interest requires so, provided that the case is closely linked to another legal field.

These provisions are primarily considering the meaning and functions of public policy from the viewpoint of international private law, but- as it will be shown in detail later onare in close relation with the meaning of public policy that relates to the invalidation of arbitral awards. In connection with this we must refer to Art. 190 of the IPRG, which contains the rules for revoking of the arbitral award and which-having regard to our topicit seems appropriate to quote verbatim:

Art. 190. IX. Endgültigkeit, Anfechtung

1. Grundsatz

1. Mit der Eröffnung ist der Entscheid endgültig.

2. Der Entscheid kann nur angefochten werden:

a. wenn der Einzelschiedsrichter vorschriftswidrig ernannt oder das Schiedsgericht vorschriftswidrig zusammengesetzt wurde;

b. wenn sich das Schiedsgericht zu Unrecht für zuständig oder unzuständig erklärt hat;

c. wenn das Schiedsgericht über Streitpunkte entschieden hat, die ihm nicht unterbreitet wurden oder wenn es Rechtsbegehren unbeurteilt gelassen hat;

d. wenn der Grundsatz der Gleichbehandlung der Parteien oder der Grundsatz des rechtlichen Gehörs verletzt wurde;

e. wenn der Entscheid mit dem Ordre public unvereinbar ist.

3. Vorentscheide können nur aus den in Absatz 2, Buchstaben a und b genannten Gründen angefochten werden; die Beschwerdefrist beginnt mit der Zustellung des Vorentscheides.

According to Art. 190 of the IPRG the enactment of the arbitral award shall be of legally binding and final. The arbitral award may be invalidated in the event of:

a) if the single judge or the selection of the arbitration panel was not drawn up according to the applicable rules;

b) if the tribunal was mistaken in finding it's jurisdiction or the refusal of it's jurisdiction;

9 „Die Abwendung von Bestimmungen eines ausländischen Rechts ist ausgeschlossen, wenn sie $z$ e einem Ergebnis führen würde, das mit dem schweizerischen Ordre public vereinbar ist." This Clause shows similarity with The Hungarian International Private Law Codex, Decree Law 13 of 1979 like force Clause 7. subpara. 1. In connection with this see Burián, L.-Kecskés, L.-Vörös, I.: Magyar nemzetközi kollíziós magánjog (Hungarian International Private Law). Budapest, 1997. 137143. 
c) if the content of the tribunal's award went beyond the request provided, or failed to decide on issues that were included in the application;

d) if the principle of equal treatment of parties, or the principle of hearing of the Parties was injured;

e) where the award of the tribunal was incompatible with public policy (in German and French text: ordre public, the Italian text: ordine pubblico).

It is essential to note that the invalidation of the interim arbitral award may only be applied for in the case of a) and b) cited above. In case of Art. 191 the Swiss Federal Court (Schweizerische Bundesgericht) is competent to invalidate a foreign arbitral award. There is a 30-day long deadline for the submitting of the invalidation petition starting on the day of the conveyance of the award. In the international arbitration proceedings, the arbitration award may be considered conveyed if it has been delivered to the parties, except if the given arbitration rules require otherwise. However, in the Swiss domestic arbitration proceedings-unless otherwise agreed upon by the parties-the arbitration award shall be deposited with the competent court according to the seat of the arbitration court, which will notify the parties of the award. ${ }^{10}$

Although this study does not deal with the Swiss domestic arbitration, it is essential to emphasize that the Swiss domestic arbitration unlike the international commercial arbitration provides further opportunities to invalidate the arbitration award since invalidation is possible to be sought on the grounds that the award is arbitrary, based on obviously incorrect facts or on the clear breach of the law. ${ }^{11}$

\section{II.}

The details of the IPRG that are found in separate places in relation to public policy are in close contact with each other in case we examine the role of public policy played in the arbitration proceedings. Although Art. 190 of the IPRG mentions conflict with public policy, in relations with the revoking of the arbitration award and the New York Convention on the recognition and enforcement of arbitration awards signed on the 10th of June 1958 (The New York Convention) mentions public policy in the second paragraph of subparagraph b) of the V. Article in relation with the recognition and enforcement of the arbitral award, the concept of public policy-as it is also pointed out by Karl-Heinz Böckstiegel-starts long before the arbitration proceedings begin, for example, because it serves as a limit of the parties self autonomy to which cases are judged via arbitration, and therefore the lack of settling disputes via arbitration (lack of arbitrability) can often play a large role in the public policy clause. ${ }^{12}$

10 See Segesser, G. V.-Jolles, A.: Switzerland. In: Rowley, J. W.-Mendelsohn, Mc. B. (eds): Arbitration World. Jurisdictional Comparisons. London, 2006². 372.

11 Article 33 of the Intercantonal Convention pays attention to the question of invalidation of a domestic arbitration award. The comparison of this with international arbitration proceedings see in specific Walter, G.-Bosch, W.-Brönnimann, J.: Internationale Schiedsgerichtsbarkeit in der Schweiz. Kommentar zu Kapitel 12 des IPR-Gesetzes. Bern, 1991. 225.

12 See Böckstiegel, K. H.: Public Policy as a Limit to Arbitration and its Enforcement. In: IBA Journal of Dispute Resolution. Special Issue, 2008. The New York Convention-50 years. 123. 
(Taking account of public policy-and the international private law meaning ascribed to it-during the arbitration process is of the utmost importance, because failure to provide it may serve as a very good argument that the substantive part of the award shall be invalidated by reference to a conflict with public policy.)

The established view in the case law is that this is an exceptional provision to be used, which may be relevant in cases where the violation of law and justice exceeds a level, which is contrary to law in its Swiss concept.

For example, the negative public policy clause contained in Art. 17 of the IPRG shall not prevent the application of Saudi Arabian law, which prohibits the imposition of interest. $^{13}$

It is essential to point out-as Francesco Tezzini does-that while the Art. 17 of the IPRG uses the concept of Swiss public policy (schweizerische Ordre public) while reading the concept of public policy contained in Art. 190 of the IPRG on invalidation of arbitration awards we come across "merely" the concept of public policy without any reference to Switzerland. ${ }^{14}$ This will have particular importance during the interpretation of Art. 190 Para. 2 e) of the IPRG.

By contrast Arts 18 and 19 of the IPRG shall be considered as a kind of positive public policy clause, since in this case we can find an essential a public policy interest that requires a particular application of the law, as opposed to the public policy exclusion clause in Art. 17 of the IPRG. This is particularly important in the Swiss case law in case of the application of prevailing legal standards of a state are cogent. In the case of Switzerland, this clearly occurs in cases where any of the European Community law would be applied.

The Swiss Federal Court in a famous decision made in the Gamma vs SA. Sigma SA case on the 28th of 1992 defined important criteria in this issue. In this case, the parties stipulated Belgian law ruling in their contract and by that included European Community antitrust laws as they are a part of Belgian law. The Federal Court held that it would be a violation of public policy of the European Community if an arbitration award would be inconsistent with Art. 81 (ex-Art. 85) of the Treaty of Rome. Accordingly it is an obligation of the arbitrators to examine the agreements before them in order to avoid the decisions made that are incompatible with community law. ${ }^{15}$ The position established in this case by the Federal Court has been further refined in a decision made on the 13th of November 1998. According to the facts of the case the parties entered into a licensing agreement, in which Swiss law was governing, but under the contract some of the deliverables were to be accomplished in the territory of the European Community.

During the arbitration proceedings neither party referred to a possible breach of the EU's competition rules-Art. 81 of the Treaty of Rome-the arbitrators themselves did not investigate this aspect of the matter. The Federal Court held that it is an obligation of the arbitrators to examine the contract under Art. 81 of the Treaty of Rome-even if the parties deemed Swiss law governing-in case when at least one of the parties referred to the contract

13 See Vischer, F.: IPRG Kommentar. (Heini, A.-Keller, M.-Siehr, K.-Vischer, F.-Volken, P. eds), Zürich, 1993. Art. 17, N. 1, 7.

14 See Trezzini, F.: The Challenge of Arbitral Awards for Breach of Public Policy according to Art. 190 para. 2 lit e) of the Swiss Private International Law. In: Three Essays on International Commercial Arbitration. Lugano, 2003. 127.

15 See: DFT 118. II. 193. In relation with the decision see Trezzini: op. cit. 135-136. See further Blessing: op. cit. 247-248. 
being invalid during the judicial or arbitral proceedings. ${ }^{16}$ According to this perception in case if the arbitrators cannot do that, then the decision may be invalidated based on Art. 190 Para. 2 e) of the IPRG, according to which the tribunal erred in finding or denying jurisdiction. A specific trait of this decision is that such a strong standpoint wad drawn up by the supreme court of a non-EU member state.

The interpretation of the above-quoted Arts 17 and 18 of the IPRG was raised in the Federal Court decision made in Lausanne on the 28th of March 2001, too. Here, the question was whether a treaty condemning the Swiss law governing, that breaches foreign mandatory rules-the UN resolution on a weapons embargo in the territory of the former Yugoslavia-, may be contrary to Art. 20 of the Swiss OR on good faith. ${ }^{17}$ The decision held the contract was in breach of good faith, but by no means by the direct application of the $\mathrm{UN}$ resolution, but by the breach of public policy. As you can see, that in this decision Arts 17 to 19 and Art. 190 Para. 2 e) of the IPRG are jointly applied.

\section{III.}

The following is an overview of the interpretation which the Swiss arbitration practice has developed of Art. 190 Para. 2 e) of of the IPRG that is the basis on which the invalidation of an arbitration award may be claimed if the judgment is contrary to public policy. With regard to the fact that this provision-as it has been mentioned previously-concerns international commercial arbitration, it is essential to compare this rule with the New York Convention cited above, of which subparagraph Art. V. paragraph 2 b) states the following:

2. The recognition and enforcement of an arbitration award may also be refused if the competent authorities of the country in which recognition and enforcement is sought finds that: b) The recognition or enforcement would be contrary to public policy in this country. ${ }^{18}$

In comparison of the provisions of the New York Convention and the IPRG, a striking difference is that the IPRG makes the invalidation of the award possible if it is contrary to public policy while the New York Convention allows the invalidation of the award on the grounds of it being contrary to the public policy of the state recognizing and implementing the award. ${ }^{19}$ The question is instantly raised what the difference is between the concept of a country's public policy and the international concept of public policy.

${ }^{16}$ See DFT 13.11.1998. See further Trezzini: op. cit. 138. Trezzini emphasizes that according to some authors the members of the tribunal should take into consideration Art. 81 of the Treaty of Rome if neither party referred to the cases relations with competition law. See further Blessing: $o p$. cit. 247-248.

17 The first paragraph of Art. 20 of the Swiss OR defines the breach of good faith by contracts as such: „Ein Vertrag, der einen unmöglichen oder widerrechtlichen Inhalt hat oder gegen die guten Sitten verstösst, ist nichtig."

18 The New York convention was implemented into Hungarian law by Decree-Law No. 25/1962.

${ }^{19}$ It is an important part of the cited article of the New York Convention that recognition for states is not compulsory and that the question of denial of enforcement on grounds of violation of public policy is at the discretion of the court. 
Although the wording of the New York Convention is clear about the public order of the country given, due to the international nature of the arbitration proceeding it-the concept of international aspects of the subject-makes it essential to be aware of the international aspects of public policy. ${ }^{20}$ In some countries the case law also places great emphasis on the investigation of this issue. The manual of Martin Hunter-Alan Redfern refers to a specific case in India. The Supreme Court of India in the case of Renusagar Power Co. Ltd. v. General Electric Co. made the following stance:

"This raises the question of whether the narrower concept of public policy as applicable in the field of public international law should be applied or the wider concept of public policy as applicable in the field of municipal law. The Court held that the narrower view should prevail and that enforcement would be refused on the public policy ground if such enforcement would be contrary to (i) fundamental policy of Indian law; or (ii) the interests of India;or (iii) justice or morality."21

According to the Supreme Court of India a narrower concept of public policy should be applied when the recognition and enforcement of arbitration awards are concerned, but throughout the detailed discussion of this matter explains that the recognition and enforcement of an arbitration award on the grounds of it being contrary to public policy may be possible if it is contrary to the fundamental policy, the interests of India, or the concept of morality and justice. As one might see this public policy clause has a somewhat broader interpretation than the concept of international public policy due to the position held by the Supreme Court of India.

In Swiss case law in Art. 190 Para. 2 e) of the IPRG the substantive law meaning and the procedural law meaning of public policy is clearly distinguishable. The essence of the procedural law public policy is that each party should be granted the right to an irrespective judgment that is an appropriate procedure, the adequate portrayal and evaluation of facts. The substantive law public policy means firstly the fundamental principles of the rule of law, the intrinsic values which all arbitration awards must respect.

During the interpretation of the procedural public policy several notable cases can be found in the Swiss case law. It was held that the mere fact that an arbitration award has no justification is not a procedural violation of public policy. In reference to the independence of the experts used by the tribunal independence, used by experts for the Swiss Federal Court has thus held a position that, until an expert has no personal interest in the outcome of a legal proceedings there can be no talk about violations of public order. ${ }^{22}$

The Swiss Federal Court came to a very interesting conclusion in relation to the procedural public policy in another case. In the event that the tribunal gives an opportunity for certain facts to be considered as evidence, but later on lets the parties know that these facts were not portrayed in an appropriate way (and therefore will not consider them), we may talk about the violation of procedural public policy. However, if the tribunal gives the

20 In relation to this see Carbonneau, T. E.: Alternative Dispute Resolution. Melting the Lances and Dismounting the Steeds. Chicago, 1989. 66-67.

21 The case of Renusagar Power Co. Ltd. v. General Electric Co. was quoted by Redfern, A.Hunter, M.: Law and Practice of International Commercial Arbitration. London, 20044. 473.

22 In connection with this see Müller, Ch.: International Arbitration. A Guide to the Complete Swiss Case Law (Unreported and Reported). Zürich-Basel-Geneva, 2004. 180-181. 
authorization for the attachment of such evidence, then later on-the Federal Court ruled that-without the breach of good faith without prejudice to its decision may not arbitrarily change it. The Federal Court also points out that by doing so the tribunal violates the contractual legal relationship existant between the tribunal and the parties and that is contrary to the theory pacta sunt servanda. ${ }^{23}$

In my opinion, this case is very interesting in two respects. Firstly, the argument mentioned above is good at relating the concept of procedural and substantive public policy also highlighting the fact that there is a kind of contractual relationship between the parties, because the parties subjected themselves to the tribunal's decision, instructed the tribunal to make a judgment in the matter and due to this analogy the tribunal also bares certain obligations. ${ }^{24}$

As far as the substantive public policy concept is considered, here the acting tribunalthat is the Swiss Federal Court-is responsible for considering for specific matters whether there has been a secondary offense, which is contrary to the fundamental principle of the rule of law.

Based on the available case law of the pacta sunt servanda principle, a serious violation of the principle of good faith, the prohibition of the abuse of power, that is in fact the violation of a principle with an apparently significant moral content of private international law may justify the violation of public policy from the substantive point of view.

The Federal Court in a case held that it may be viewed as the violation of good faith with particular attention to the violation of culpa in contrahendo-and shall therefore be considered as basis for the invalidation of an arbitration award for the violation of public policy-if either party during the contracting process fails to provide all necessary information that the other party did not know about and could not have known about that was needed for the other party to make an informed decision. ${ }^{25}$ The view of the Federal Court is of fundemental importance that the violation of good faith and the abuse of power materialised so that the arbitration award may be invalidated on the grounds of it being contrary to public policy shall be examined via the second article of the Swiss OR. ${ }^{26}$

23 In connection with this see Müller: op. cit. 190.

${ }^{24}$ It seems appropriate to refer to the fact that this quality of modern day arbitration shows much relation to the concept of arbitration in Roman Law, where the receptum arbitrii known as pactum also emphasizes the contractual nature of the legal relationship. For the concept of receptum arbitrii see Földi, A.-Hamza, G.: A római jog története és institúciói (The History and Institutions of Roman Law). Budapest, 2009 ${ }^{13}$. 542. For the arbitration in Rome see Roebuck, D.-De Loynes de Fumichon, B.: Roman Arbitration. Oxford, 2004. For the legal nature of the arbitration contract see Ujlaki, L.: A választottbírósági szerződés jogági elhelyezettsége és tipológiája (The legal position and typology of the arbitration agreement). Jogtudományi Közlöny, 46 (1991), 216-225.

25 See Müller: op. cit. 191.

${ }^{26}$ Article 2 of the OR points out that „Haben sich die Parteien über alle wesentlichen Punkte geeinigt, so wird vermutet, dass der Vorbehalt von Nebenpunkten die Verbindlichkeit des Vertrages nicht hindern solle. Kommt über die vorbehaltenen Nebenpunkte eine Vereinbarung nicht zustande, so hat der Richter über diese nach der Natur des Geschäftes zu entscheiden. Vorbehalten bleiben die Bestimmungen über die Form der Verträge." 
Therefore the good faith procedure demanded at the creation of contractual obligation prescribed by Swiss private law acts as a canon during the invalidation process of an arbitration award on the grounds of it being contrary to public policy. ${ }^{27}$

\section{IV.}

In Swiss case law/practice the Court of Arbitration for Sport, CAS (Tribunal Arbitral du Sport) plays a unique role in the viewpoint evolved in relation to the invalidation of an award on the grounds of collision with public policy. The CAS was founded by the International Olympic Association. The CAS is based in Lausanne it is an arbitrary institution judging cases involving international legal matters under Swiss law. ${ }^{28}$

Numerous requests for the invalidation of the decision on the grounds of it being contrary to Swiss public policy made by the CAS have been submitted to the Federal Court also based in Lausanne. The Federal Court has rejected all requests based on the decision being in conflict with substantive public policy. ${ }^{29}$ The Federal Court in sports-law cases held that the concept of conflict with public policy shall be viewed as an international concept rather then a domestic one, which in essence prohibits the recognition and enforcement of judgments that are incompatible with fundamental legal or moral principles established in civilized countries.

In the case of Marc Biolley v. Association Turkish FA in 2007 the Federal Court held that an award is contrary to substantive public policy if it breaches such fundamental rules of substantive law that by doing so it becomes incompatible with the present rule of law and system of values. In the interpretation of the Federal Court such is the prohibition of the abuse of law and what is even more substantial in sports law questions the prohibition of discriminating provisions and the protection of incapacitated persons.

Several requests for invalidation have been submitted against rulings by the CAS of the grounds of them being contrary to the principle of good faith and the equal treatment and are therefore contrary to Swiss public policy.

It is worth referring to the case of Raducan v. IOC in the year 2000 Sydney Olympic Games, acting under the CAS ad hoc arbitration tribunal found that Romanian female gymnast, Andreea Raducan, who had admittedly taken a pill containing a banned ingredient had commited a doping violation. Andreea Ruducan later on based her request for invalidation on the fact that there was an inexplicable difference in the quantity of the urine sample provided by her during the doping test $(100 \mathrm{ml})$ and the urine sample examined by the laboratory $(62 \mathrm{ml})$ and due to this the arbitration body should not have judged the claim

27 In connection with good faith in Swiss law see Földi, A.: A jóhiszemüség és tisztesség elve. Intézménytörténeti vázlat a római jogtól napjainkig (The principle of good faith and honesty). History of Institution from Roman times till today). Budapest, 2001. 48-52. The second Article of the ZGB for the concept of good faith uses the expressions Treu und Glauben, bonne foi, and buona fede.

28 The quite informative website of the CAS is: http://www.tas-cas.org/ In connection with the functions of the arbitration besides the regulation and certain decision on the website see in detail Blackshaw, I. S.-Siekmann, R. C. R.-Soek, J. (eds): The Court of Arbitration for Sport: 1984-2004. The Hague, 2006.

29 In connection with this see Mitten, M. J.: Judicial Review of Olympic and International Sports Arbitration Awards: Trends and Observations. Marquette University Law School Legal Studies Research Paper Series, (2009) 9-14, 9. see http://ssrn.com/abstract=1376317. 
as it has done previously in another case where the integrity of the urine sample was not sufficiently justified the examined sports fellow was not condemned and according to the Romanian gymnast her conviction was violation of the principle of equal treatment.

According to the Federal Court that fact that Andreea Raducan made a statement during the process that resulted in her admitting to taking the pill containing a banned ingredient makes this case completely different to the one referred to in the request for invalidation and therefore we may not speak of the violation of equal treatment. ${ }^{30}$

From the point of view of our topic it is even more interesting to take into account the fact whether the seat of the CAS arbitration is always seen as Lausanne-regardless of where geographically speaking the Arbitration Board's proceedings are actually conducted-and whether the procedure is governed by Swiss law. Thus the CAS arbitral judgments-except in Switzerland-may be viewed as a foreign arbitration award, which in case of recognition and enforcement of judgments is to be considered under the public policy clause of the New York Convention subpara. e) of Article V.

In the case law of the United States we can experience in several cases that the judgment made by the CAS was applied for to be invalidated on the grounds of collision with public policy.

It is worthwhile mentioning the case of Slaney v. International Amateur Athletic Federation. ${ }^{31}$ According to the facts of the case a medium distance runner female sports fellow had an increased ratio of testosterone to episterone of 6:1. According to the rules of the International Amateur Athletic Federation this increased ratio suggests that the athlete was using a banned substance for doping which presumption may be rebutted by the athlete submitting clear and convincing evidence, demonstrating that the increase was due to a physiological or pathological state. During the process Mary Slaney failed to produce such evidence.

Her intention was to invalidate the judgment on the grounds that it is in collision with the public policy of the United States of America that the conviction relies on a test which is scientifically invalid and is discriminative against female athletes. The Second Circuit Court of the USA denied her request pointing out that the recognition and enforcement of an arbitration award may only be denied on a small scale of the public policy clause of the New York Convention. This is only possible in the case of when the judgment would be in violation of the fundamental concepts and the enforcement of the judgment would be contrary to a paramount principle of law. According to the viewpoint of Second Circuit the rules above-mentioned and the procedures for determining may in no way be viewed as one that is in accordance with the conditions of the application of the public policy clause.

In connection with this Matthew J. Mitten-in light of the position held by the Swiss Federal Court and the courts of the USA-draws the conclusion that the public policy clause in connection to the recognition of arbitration awards in connection to the Olympic Games and international sports instead of individual national approaches shall be interpreted throughout a transnational concepts of universal lex sportiva.

This approach according to Mitten actually meets the objective set by Judge Pierre Coubertin which states that it is an important goal for the olympic movement to respect the fundamental ethical principles. ${ }^{32}$

\footnotetext{
30 In detail see Mitten: op. cit. 11-12.

31 For summary of the case see Mitten: op. cit. 15-16.

32 In connection with this see Mitten: op. cit. 17.
} 
As a counter example Matthew J. Mitten-and with a critical opinion-refers to a judgment made by the European Court in 2006. In the case of Meca-Medina and Majcen v. Comm'n of European Communities the European Court of Justice allowed two Slovenian swimmers to contest an arbitration award by the CAS. ${ }^{33}$ The arbitration tribunal in its judgment moderated the suspension of doping misdemeanor at the Brazil swimmers world cup from four years given by the International Swimmers Association Federation Internationale de Natation, FINA) to two years. The European Court of Justice allowed the case to be retried with the conditions to view if the two year suspension was proportionate in light of the provisions ordering the freedom of competition and services in the Treaty of Rome. According to the European Court of Justice these sports law provision by prohibiting the swimmers from part-taking in professional swimming and challenges have a distinct economic impact on the swimmers and it should be investigated if these doping rules are compatible with the above-mentioned principles of the European Community law.

It is of the utmost importance to note that the European Court of Justice found that the criteria defined in the doping rules are adequate and the sanctions are not disproportionate, not excessive, that is not contrary to European Community competition law, but it seems that the European Court of Justice in this case appears to have taken into account other considerations than just those defined in the New York Convention or the Swiss IPRG in the decision of invalidating of the CAS arbitration award.

According to Mitten the opinion set out in the above-cited case is unlucky because it might result in the suppression of the evolution of cohesive legal interpretation of international Olympic games and international sports whereas according to Mitten's opinion the achievement of such an international sports legal system would be salutary in which the achievement of a homogenic interpretation of public policy should be achieved. ${ }^{34}$

V.

In order to understand whether the Swiss case law considers the concept of public policy international or transnational it is expedient to refer to a judgment made by the Swiss Federal Court in 1995 that the manual of Hunter-Redfern describes in detail. ${ }^{35}$ According to the justification of the judgment during the recognition and enforcement of a foreign arbitration award in-when clearly implied that the international aspects of public policy must be borne in mind-a Swiss court has a very narrow margin. In view of the Swiss Court if the recognition and enforcement should be denied on grounds of a procedural error then this is possible only in the case if the procedural error is contrary to the fundamental principles of the Swiss jurisdiction or is in serious violation of the sense of justice.

In another case the Federal Court came to the guiding position that Art. 190 Para. 2 e) of the IPRG should be interpreted by taking into consideration of the universal concept of public policy which is independent from the dispute and applicable substantive law.

33 See the whole case at http://eur-lex.europa.eu/LexUriServ/LexUriServ.do?uri=OJ:C:2006:224:0008:0008:EN:PDF

See the bulletpoints of the case at http://curia.europa.eu/jcms/upload/docs/application/ pdf/2009-02/cp060065en.pdf

34 In connection with this see Mitten: op. cit. 19.

35 See Redfern-Hunter: op. cit. 473. 
The violation of public policy is distinguishable if the judgment is contrary to the ethical values of the civilized countries, which values are therefore to be valid above at an above all nations. ${ }^{36}$

The above-quoted Trezzini summarizes the respected Professor Pierre Lalive's opinion that invalidation on grounds of the public policy clause has three known levels. Firstly one may speak of the domestic public policy concept which arises as a result of national provision and may prevail in domestic conditions. Secondly one may mention the Swiss public policy which is of national origin but is applied in the international dimension and thirdly the supranational and transnational and really may refer to the international public policy which is not the product of the national jurisdiction but the public policy concept which may be derived from the civilized countries and the perception and attitude of international commerce. ${ }^{37}$

From those mentioned above the conclusion can be drawn that in the dimension of international arbitration the application of the transnational concept of pubic policy is salutary. In case of this public policy concept-as it may be seen from the case cited abovethe strict distinction between the concept of substantive and procedural public policy seems artificial. However, it is important to conclude that when defining the concept of international public policy covered by sacrosanctus legal values it is almost impossible to proceed without the implantation of individual countries, legal cultures and morals.

36 See Müller: op. cit. 171.

37 See Trezzini: op. cit. 131. See further Lalive, P.: Ordre Public transnational ou réellement international et arbitrage international. Revue de l'Arbitrage, 1986. 329 sqq. 